\title{
A simple notation scheme to describe time-averaged ostracod assemblages (Crustacea, Ostracoda) by their taxonomic composition
}

\author{
H.I. GRIFFITHS \\ School of History and Archaeology, \\ University of Wales College of Cardiff, \\ PO Box 909 \\ Cardiff, CF1 3XU, UK.
}

\author{
J.G. EVANS \\ School of History and Archaeology, \\ University of Wales College of Cardiff, \\ PO Box 909, \\ Cardiff, CF1 3XU, UK
}

\begin{abstract}
A simple notation scheme is presented for the description of Quaternary freshwater ostracod assemblages by means of their taxonomic composition. The notation scheme also allows diagrammatic description of the fauna and assists in palaeoecological interpretation of sequential samples. J. micropalaeontol., 11(1): 31-35, June 1992.
\end{abstract}

\section{INTRODUCTION}

In recent years there has been an increasing trend towards the use of sub-fossil invertebrate remains in environmental archaeology. As yet, one of the least familiar of these techniques is the application of ostracod analysis in wetlands archaeology for palaeoenvironmental, palaeoclimatic and palaeohydrological studies. Although Ostracods have been used in Quaternary palaeoecology for many years, the first published instance of their integrated use in archaeology appears to have been by R.W. Meyrick, in a report on the environment of Roman York (Buckland, 1976). To date archaeological studies in which the ostracoda have been examined are few, e.g. Whatley \& Haynes (1986), McKenzie (in press). However, in a small number of studies material has been examined in stratigraphic series; Robinson (1986) discussed ostracods from the Bronze-Age trackways at Mere Village East on the Somerset Levels, and more recently, Bradbury et al. (1990) have reported on sequences from Mayan wetland agricultural deposits from Belize. Further works within archaeological contexts include the examination of the fauna of a travertine lens associated with a Homo erectus find (Diebel \& Pietrzeniuk, 1980), various studies of Late-glacial and Holocene tufas (Preece \& Robinson, 1984; Preece et al., 1986) and earlier, Middle Palaeolithic deposits (Fuhrmann \& Pietrzeniuk, 1990).

The concept of uniformitarianism has dominated the thinking of many ostracod workers regardless of their environmental or temporal specialities (Neale, 1983). Even the sophisticated approaches adopted in palaeolimnological studies depend, to a great extent, on a uniformitarian approach to obtain climatic and environmental information (e.g. Delorme, 1971, 1989). However, the adoption of any such approach depends upon the validity of two core concepts:

(1) That identicality of morphology reflects ecological identicality. This view is particularly attractive when dealing with late Pleistocene and Recent faunas, and the oft-quoted (although largely apocryphal) view of the Ostracoda as being evolutionarily conservative has done much to reinforce this concept.

(2) That past environments have analogues in the present and that modern environmental sets are fully equitable and similar in terms of stability, equilibria, etc.

Doubts have been expressed with regard to the validity of both of these viewpoints (Gee \& Giller, 1991), and in some cases (e.g. Guthrie, 1990) it is clear that a true analogue amongst modern environments is simply not available. Similarly, the great tufa depositions of the Atlantic (and earlier) periods appear to have no genuine modern analogue (Preece, 1980). Often Holocene environmental processes are poorly understood, and recent studies underline the lack of uniformity in response of apparently equivalent environments to similar pressures (Burrin \& Scaife, 1988).

Many workers have also doubted the validity of direct comparisons between the ecologies of fossil and modern species and this, coupled with the paucity of zoological data, has led some to search for alternative approaches (Absolon, 1973; Forester, 1991). One recent study does provide some evidence that the ecology of at least one species, Nannocandona faba Eckman, has shifted since the last glacial (Marmonier \& Danielopol, 1988). Although the evolutionary conservancy of the group has been used to great advantage in some marine studies (e.g. Cronin \& Ikeya, 1990), freshwater species occupy more transient environments, where increased environmental stress and selection pressures may lead to evolutionary divergence (Hoffman \& Parsons, 1991). Recent studies by Martens (1990a) of the diversification of Limnocythere s.s. in the lakes of the East African Rift have led to the discovery of five lake-specific subspecies, derived from ancestral stocks of a giant pluvial lake. Subspeciation is postulated to have occurred by isolation in the individual lake basins through lake-level recession within the Holocene. Also important is the finding that the production of ecologically-generated morphotypes (ecophenotypes) prevents the accurate determination of several Limnocythere spp. from carapace characters alone (Martens, $1990 \mathrm{~b})$. As the ostracod carapace is subject to many functional and biomechanical constraints (Benson, 1987) natural selection would be expected to act to maintain carapace morphology under normal circumstances. According to the biological concept of species (Mayr, 1970) selection pressures tend to act 
most strongly upon labile characters, such as behaviour, to produce reproductive isolation in allopatry (Claridge, 1988).

Environmental stress appears to promote genetic diversity in a number of ways (Parsons, 1988; Hoffman \& Parsons, 1991). As the Quaternary in general, and the Pleistocene in particular, were times of great environmental fluctuation and (presumably) stress, one may expect the gulf between apparent morphology and presumed ecology to widen considerably.

\section{DESCRIBING THE TAXONOMIC STRUCTURE OF OSTRACOD ASSEMBLAGES}

Given that strict species (or even species-group) linkages to specific ecologies may be unreliable, what constitutes a suitable approach for the analysis of fossil/sub-fossil ostracod assemblages? A number of solutions have been derived from the use of techniques developed for use in modern ecology, particularly biomonitoring. These include indices of diversity or species richness, such as the Shannon-Weiner or Margalef's Indices (Magurran, 1988), and more sophisticated techniques such as TWINSPAN and DECORANA. However, the apparent simplicity of indices (in particular) may be misleading, and they should only be used when appropriate to the data under consideration (Magurran, 1988). It is important to realise that fossil and sub-fossil assemblages are not communities in the modern sense, but distinct time-averaged taxocenes (Fürsich \& Aberhan, 1990) which have undergonea variety of processes of sortage and attrition (Briggs et al., 1990; Danielopol et al., 1986).

In the case of ostracod analysis these solutions may also be adopted. However, no index gives any information on the actual structure of the assemblage under examination. Furthermore, the constraints under which modern ostracod communities develop are understood only in the most rudimentary sense (Griffiths \& Evans, 1991). Community descriptions are virtually impossible as we know so little of modern ostracod ecology, and insufficient data are available to allow community reconstructions based upon concepts such as guilds or trophic levels. Despite this, any ostracod assemblage will show something of the taxonomic nature of the fauna under examination. Taxonomic status reflects overt morphology and, because functional morphology and ecology are correlated, the taxonomic structure of an assemblage may be used to provide an objective criterion for reconstructions, without appealing to factors that may be subject to ecophenotypic variation in time and/or space.

In a given environment species composition reflects a complex interaction of abiotic and biotic factors, so that the resultant community is the product of both local environment and intra- and interspecific interactions. There are also tendencies for more speciose assemblages to derive from the most stable habitats, coupled with a transition from a preponderance of generalists to one of specialists (Leigh, 1990). Hence taxonomic descriptions of an environment have a semi-objective reality and, by describing taxonomic composition, information may be obtained on the structure and composition of the originator community. Also, sequential changes can be described in such a way that biogeographical species turn-over may be discernable from that caused by genuine ecological change. Such a viewpoint is particularly

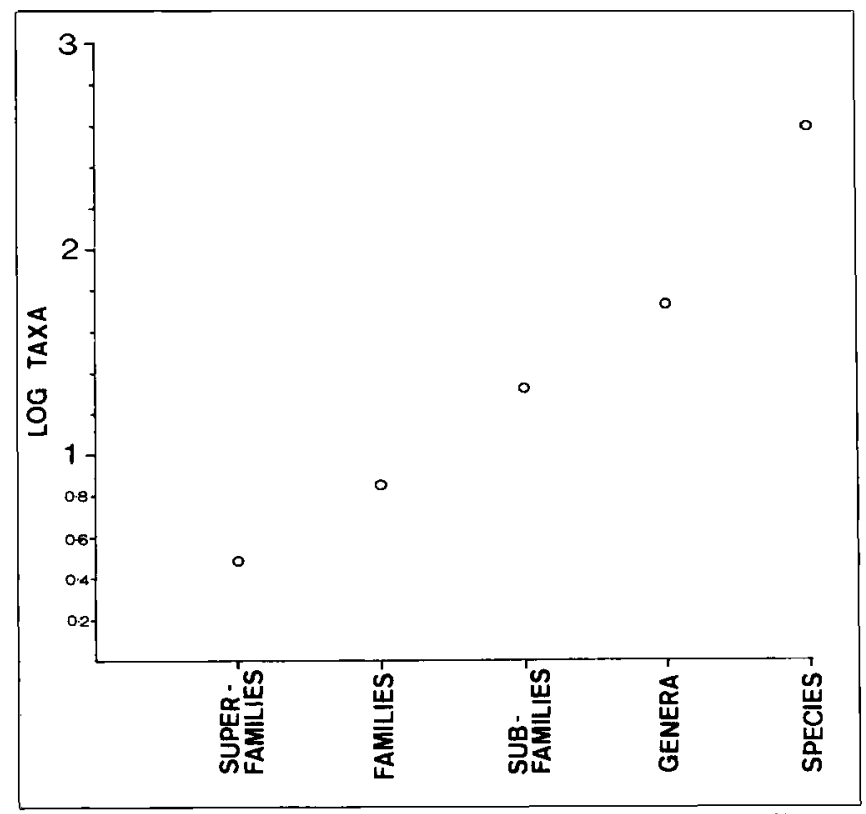

Fig. 1. Allocation of European freshwater ostracod taxa to different taxonomic levels (numerical values to $\log _{10}$ ). Derived from Löffler \& Danielopol (1978) and Meisch et al. (1990).

helpful when dealing with extended sequences of samples in stratigraphic order.

Fig. 1 shows the allocation of European freshwater ostracod taxa to different taxonomic levels. The number of species (388) is derived from Löffler \& Danielopol (1978) and the numbers of families, sub-families and genera from Löffler \& Danielopol (1978) and Meisch et al. (1990). As can be seen, the sub-familial, generic and specific levels are descriptively useful whereas the number of families largely complements the number of superfamilies (which are more useful in ecological description).

A little experimentation reveals that it is extremely difficult to construct a simple numerical tool such as a coefficient that describes these taxonomic associations. Inevitably one must employ some sort of arbitrary weighting system to assign values to the various taxonomic levels and it is difficult to produce a meaningful range of values that will allow the recognition of the level or extent of taxonomic changes. One way around these problems is the adoption of a simple notation scheme composed of three descriptive phrases; one to describe super-familial composition, the second dealing with sub-families, the last with genera and species. This eventually gives a "shorthand" description of the assemblage which may then be reconstructed as a dendrogram.

The first term deals with the super-familial composition of the taxocene. As only three ostracod superfamilies are represented in freshwater habitats (each with a very different set of biological characters) this is the only literally descriptive phrase. Thus ' $A$ ' signifies the Cypridoidea, the commonest and most diverse freshwater group, many of which produce desiccation-resistant eggs, and many are (at least facultatively) parthenogenetic. 'B' represents the Cytheroidea, dominant in marine environments, but limited to more stable, permanent water-bodies inland. None of the European cytheroids produce drought-resistant eggs and most (if not all) reproduce sexually. 
' $\mathrm{C}$ ' represents the Darwinuloidea, an ancient parthenogenetic, pouch-brooding lineage. Except in very rare cases, this last group will be represented exclusively by Darwinula stevensoni (Brady \& Robertson), although other species of genus Microdarwinula do occur in certain specialised habitats. Thus, except in exceptional circumstances, the presence of a darwinulid is always assumed to refer to D. stevensoni and is recognised only in the use of the ' $\mathrm{C}$ ' component of the first phrase.

The second term numerically describes sub-familial composition and the distribution of the genera within them. Some ostracod sub-families are specialised in both morphology and distribution. These families could be described as "effectively monospecific", i.e. composed of only a few species, of which more than one is unlikely to be present in a given habitat, e.g. Notodromatinae, Isocypridinae, Cyridinae, Cyprettinae, Cyproidinae, Dolerocypridinae, Timiriaseviinae, etc. Monospecific sub-families are designated by a superscript. The significance of monospecificity becomes apparent in the construction of taxocene diagrams (Fig. 2) and prevents information loss from between taxonomic levels. Where a second super-family is present, its composition is described in this phrase by the addition of a second number (with superscript, if appropriate).

The third and final phrase numerically describes those genera present. A fractional superscript is added to describe the number of species (numerator) and the number of species as sole representatives of their genus (denominator). The composition of a second super-familial group is similarly described. The ratio of genera/species may also be determined to describe the distribution of species within genera.

By way of an example, consider the following hypothetical ostracod fauna (effectively monospecific genera are marked with an asterisk):

\begin{tabular}{|c|c|c|}
\hline Species & Sub-Family & Super-Family \\
\hline Darwinula stevensoni & Darwinulinae* & Darwinuloidea \\
\hline Metacypris cordata & Timiriaseviinae $^{*}$ & Cytheroidea \\
\hline Limnocythere inopinata & Limnocytherinae & \\
\hline $\begin{array}{l}\text { llyocypris bradyi } \\
\text { I. gibba }\end{array}$ & Ilyocyprinae & Cypridoidea \\
\hline $\begin{array}{l}\text { Candona candida } \\
\text { C. neglecta }\end{array}$ & Candoninae & \\
\hline Notodromas monacha & Notodromatinae & \\
\hline Herpetocypris reptans & Herpetocyprinae & \\
\hline Potamocypris fulva & Cypridopsinae & \\
\hline P. arcuata & & \\
\hline P. zschokkei & & \\
\hline Sarscypridopsis aculeata & & \\
\hline Cyprois marginata & Cyproinae* & \\
\hline
\end{tabular}

Here three superfamilies are represented, nine sub-families (four of them monospecific), ten genera and fourteen species. Excluding Darwinula stevensoni, six are the sole representatives of their respective genera. Hence the fauna may be described as:

ABC. $6^{2} 2^{1} .7^{11 / 4} 2^{2 / 2}$

Where:

$\mathrm{ABC}=$ all three superfamilies are represented.

$6^{2} Z^{1}=$ there are six cypridoid (two effectively monospecific)

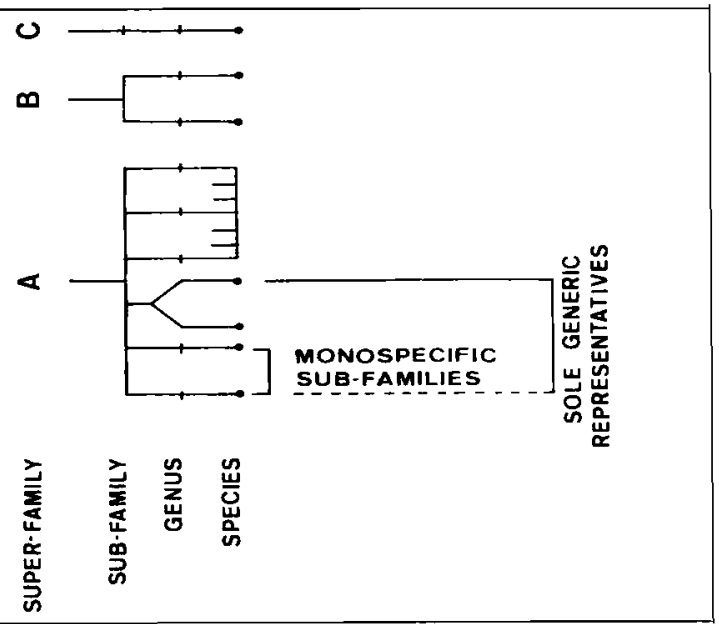

Fig. 2. Taxocene of a hypothetical freshwater ostracod fauna (see description in text).

and twocytheroid (oneeffectively monospecific) sub-families represented.

$7^{11 / 4} 2^{2 / 2}=$ There are eleven cypridoid species distributed throughout seven genera (four of which are the sole representatives of their genera).

The fauna also includes two cypridoids in different genera.

Note that the Darwinuloidea are unrecorded other than in the first phrase for the reasons previously stated.

The taxonomic structure of this community may be reconstructed as a dendrogram (Fig. 2). In this example, the genera/species ratio is $10: 14$, i.e. 0.71 (where unity represents one species.genus ${ }^{-1}$, and progressively lower values represent increases in the numbers of species distributed between genera).

In an example from the neoecological literature, Martens \& Dumont (1984) compared the ostracod fauna of Lake Donk in two surveys twenty years apart. In all, 18 species were present during the first survey and 22 during the second. The fauna from the first survey may be represented as:

\section{A. $7^{1} .12^{19 / 6}$}

Here the genera:species ratio is $12: 19$, i.e. 0.63

The results of the $1983 / 4$ survey were

ABC. 5 1.13 ${ }^{20 / 8} 1^{1 / 1}$

The genera:species ratio (including $D$. stevensoni) is $15: 22=$ 0.68 .

These two faunas can be compared by reconstruction (Fig. 3). The results of the 1964-68 survey showed a slightly lower number of species, and an equivalent number of sub-families, but with the fauna restricted entirely to the Cypridoidea. The development of the $B$ and $C$ components of the fauna shows a shift towards colonisation by fully-permanent lacustrine taxa. The main shift of emphasis is at the sub-familial level, with the loss of one specialised form (Notodromas monacha) and colonisation by non-cypridoids, coupled with more even exploitation at the generic level. Overall there is an increase in taxonomic range over time, reflected by reduced congenericity. This argues for the ecological stabilisation of Lake Donk and a resultant increase in efficiency of niche utilisation. This has occurred despite the loss of one overt niche (Notodromas inhabits the meniscus). As Notodromas is the only genus that can occupy 


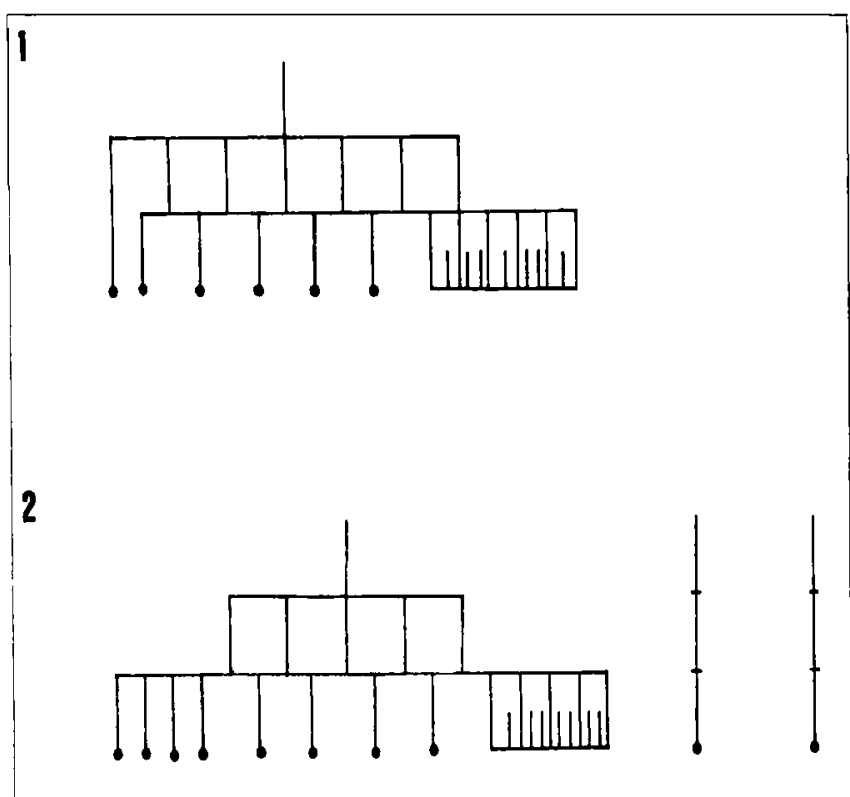

Fig. 3. Changes in the ostracod fauna of Lake Donk (Flanders) over twenty years; (1) 1964-1968 survey, (2) 1983-1984 survey. Based on Martens \& Dumont (1984).

this niche, should the environment become inimical to it, there is little chance of replacement by an incoming opportunist.

In a final example from the Late glacial of northern Germany, the fossil lake at Stellmoor, near Hamburg (Evans \& Griffiths, unpublished data), a fauna derived from the end of the Bölling-Alleröd is composed of; Darwinula stevensoni, Limnocythere inopinata, L. sanctipatricii, Fabaeformiscandona protzi, Candona candida, C. neglecta, Pseudocandona compressa, Cyclocypris ovum, Cypria ophthalmica, Ilyocypris sp. and Herpetocypris reptans. Here $G: S=9: 11=0.82$ and the fauna may be represented as:

ABC.3 1.7 $\mathbf{7}^{8 / 6} \mathbf{1}^{2 / 0}$

At the commencement of the Younger Dryas the fauna is substantially restricted $(\mathrm{G}: \mathrm{S}=3: 45=0.75)$ :

AB.1 $1.2^{2 / 2} 1^{2 / 0}$

However, as the Younger Dryas progresses, the fauna develops and diversity increases $(G: S=7: 10=0.70)$ :

ABC. $11^{1.5}{ }^{7 / 3} 1^{2 / 0}$

Here the essential changes are from the occupation of broadly-defined niches in a lacustrine water-body during the Bölling-Alleröd, to a taxonomically restricted cold-stage fauna, which is augmented during the climatic amelioration at the end of the Late-glacial. The highly circumscribed fauna of the Youngest Dryas represents a period of environmental stress, in which few taxa can survive, as shown in Fig. 4. The assemblages present certainly indicate profound environmental change.

\section{CONCLUSIONS}

By the use of a succinct notation, the taxonomic structure of a palaeocommunity can be used in environmental reconstruction to describe changes in those assemblages over time. Arguably, the use of such a system renders redundant much taxonomic debate over whether particular specimens should beconsigned to one named taxon rather than another. Here the taxonomic
1
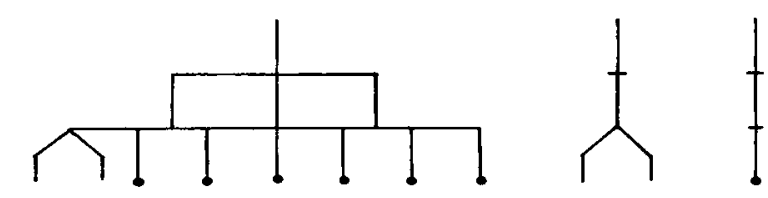

2<smiles>CCC(C)CC</smiles><smiles>CCC(CC)CI</smiles>

3
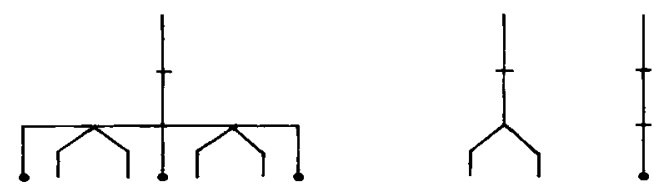

Fig.4. Ostracod assemblages from the ancient lake at Stellmoor, northern Germany; (1) Late Bölling-Alleröd, (2) Early Younger Dryas, (3) Late Younger Dryas.

whole is more important than its parts, and it is more important to know that one has three species of Pseudocandona, rather than to assign them to named species categories, followed by environmental reconstruction based on supposed ecologies. This devalues the need to search for "indicator species" of dubious palaeoecological value.

Although this system is designed for use in freshwater ostracod palaeoecology, there is no reason why it should not be adapted to the study of other taxonomically-restricted fossil or sub-fossil assemblages utilised in the reconstruction of palaeoenvironments.

\section{ACKNOWLEDGEMENTS}

Many thanks to M. Fishpool and A.J. Rouse for their helpful comments on some of the ideas discussed. K.G. McKenzie kindly provided a preprint of his, as yet unpublished, studies at Khok Phanom Di. We would also like to thank our colleagues in the USA and Europe for their continued encouragement and support. This study was funded by the Science and Engineering Research Council.

Manuscript received February 1991

Revised Manuscript accepted December 1991

\section{REFERENCES}

Absolon, A. 1973. Ostracoden aus einigen Profilen spät und postglazialer Karbonatablerungen in Mitteleuropa. Mitt. Bayer, Staatssamml. Paläont. hist. geol, 13, 47-140.

Benson, R.H. 1981. Form, function and architecture of ostracode shells. Ann Rev. Earth Planet. Sci., 9, 59-81.

Bradbury, J.P., Forester, R.M., Bryant, W.A. \& Covich, A.P. 1990. Palaeolimnology of Laguna de Cocos, Albion Island, Rio Hondo, Belize. In: Pohl, M.D. (Ed.), Ancient Maya Wetland Agriculture. Excavations on Albion Island, Northern Belize. pp. 119-154. Westview Press, Boulder. 
Briggs, D.J., Gilbertson, D.D.\& Harris, A.L. 1990. Molluscan taphonomy in a braided river environment and its interpretation for studies of Quaternary cold-stage faunas. J. Biogeog., 17, 623-637.

Buckland, P.C. 1976. The environmental evidence from the Church Street Roman sewer system. (The archaeology of York, Vol. 14, Fasicule 1). pp. 31-32. British Council for Archaeology for the York Archaeological Trust, London.

Burrin, P.J. \& Scaife, R.G. 1988. Environmental thresholds, catastrophe theory and landscape sensitivity; their relevance to the impact of man on valley alluviation. In: Bintliff, J.L., Davidson, D.A. \& Grant, E.G. (Eds), Conceptual Issues in Environmental Archaeology. pp. 211-232. Edinburgh University Press, Edinburgh.

Claridge, M.F. 1988. Species concepts and speciation in parasites. In: Hawksworth, D.L. (Ed.), Prospects in Systematics. pp. 92-111. Clarendon Press for the Systematics Association, Oxford.

Cronin, T.M. \& Ikeya, N. 1990. Tectonic events and climatic change; opportunities for speciation in Cenozoic marine Ostracoda. In: Ross, M.\&Allmon, W.D., (Eds), Causes of Evolution; A Palaeontological Perspective. pp. 210-239. University of Chicago Press, Chicago.

Danielopol, D.L., Casale, L.M. \& Olteanu, R. 1986. On the preservation of carapaces of some limnic ostracodes: An exercise in actuopalaeontology. Hydrobiologia, 143, 143-157.

Delorme, L.D. 1971. Palaeoecological determinations using Pleistocene freshwater ostracodes. In: Oertli, H.J. (Ed.), Paléoécologie Ostracodes, Pau 1970. Bull Centre Rech. Pau-SNPA 5(S), 341-347.

Delorme, L.D. 1988. Methods in Quaternary ecology No.7. Freshwater ostracodes. Geosci. Canada 16, 85-90.

Diebel, K. \& Pietrzeniuk, E. 1980. Pleistozäne ostracoden vom fundort des Homo erectus bie Bilzingsleben. Ethnogr.-Archaeol. Z., 21, 26-35.

Forester, R.M. 1991. Pliocene-climate history of the western United States derived from lacustrine ostracodes. Quat. Sci. Rev., 10, 133-146.

Fuhrmann, R. \& Pietrzeniuk, E. 1990. Die Aussage derOstrakodenfauna zum Sedimentationsablauf im Intergalzialbecken, zur klimatischen Entwicklung und zur stratigraphischen Stellung des Interglazials von Neumark-Nord (Geiseltal). In: Mania, D., Thomae, M., Litt, T. \& Weber, D. (Eds), Neumark-Gröbern. Beiträge zur Jagd des mittlepaläolithischen Menschen. Veröff. Landesmus. Vorgeschichte Halle, 43, 161-166.

Fürsich, F.T. \& Aberhan, M. 1990. Significance of time-averaging for palaeocommunity analysis. Lethaia, 23, 143-152.

Gee, J.H.R. \& Giller, P.S. 1991. Contemporary community ecology and environmental archaeology. In: Harris, D.R. \& Thomas, K.D. (Eds), Modelling Ecological Change. pp. 1-12. Institute of Archaeology, London.

Griffiths, H.I.\&Evans, J.G. 1991.Some freshwater ostracods (Crustacea; Ostracoda) from South Wales. Freshwater Forum, 1, 64-72.

Guthrie, R.D. 1990. The Frozen Fauna of the Mammoth Steppes; the Story of Blue Babe. University of Chicago Press, Chicago.

Hoffmann, A.A. \& Parsons, P.A. 1991. Evolutionary Genetics and Environmental Stress. Oxford University Press, Oxford.
Leigh, E.G.Jr. 1990.Community diversity and environmental stability; a re-examination. TREE, 5, 340-344.

Löffler, H.H. \& Danielopol, D.L. 1978. Ostracoda In: Illies, J. (Ed.), Limnofauna Europaea. pp. 196-208. Gustav Fischer Verlag, Stuttgart.

Magurran, A.E. 1988. Ecological Diversity and its Measurement. Croom Helm, London.

Marmonier, P. \& Danielopol, D.L. 1988. Découverte de Nannocandona faba Eckman (Ostracoda, Candoninae) en basse Autriche. Son origine et son adaptation au milieu interstitiel. Vie Milieu, 38, 35-48.

Martens, K. 1990a. Speciation and evolution in the genus Limnocythere Brady, 1867 sensu stricto (Crustacea, Ostracoda), in the east African Galla and Awassa Basins (Ethiopia). Cour. Forsch-Inst. Senckenberg, 123, 87-95.

Martens, K. 1990b. Revision of African Limnocythere s.s. Brady, 1867 (Crustacea, Ostracoda), with special reference to the Rift Valley Lakes; morphology, taxonomy, evolution and (palaeo-) ecology. Arch. Hydrobiol., 83(S), 453-524.

Martens, K. \& Dumont, H. 1984. The ostracod fauna (Crustacea, Ostracoda) of Lake Donk (Flanders): A comparison between two surveys 20 years apart. Biol. Jb. Dodonaea, 52, 95-111.

Mayr, E. 1970. Populations, Species and Evolution. Bellnap Press of Harvard University Press, Massachusetts.

McKenzie, K.G. (in press). The ostracodes and forams. In: Higham, C. (Ed.), Excavation of Khok Phanom Di. pp. 771-778.

Meisch, C., Wouters, K. \& Martens, K. 1990. Listeannotée des ostracodes actuels non-marins trouvés en France (Crustacea, Ostracoda). Trav. Sci. Mus. d'Hist. Nat. Luxemb., 15, 1-62.

Neale, J.W. 1983. The Ostracoda and Uniformitarianism. 1. The later record; Recent, Pleistocene and Tertiary. Proc. Yorks. Geol. Soc., 44, 305-326.

Parsons, P.A. 1988. Evolutionary rates; effects of stress upon recombination. Biol. J. Linn. Soc., 35, 49-68.

Preece, R.C. 1980. The biostratigraphy and dating of the tufa deposit at the Mesolithic site at Blashenwell, Dorset, England. J. Arch. Sci., 7, 345-362.

Preece, R.C. \& Robinson, J.E. 1984. Late Devensian and Flandrian environmental history of the Ancholme Valley, Lincolnshire: molluscan and ostracod evidence. J. Biogeog., 11, 319-352.

Preece, R.C., Coxon, P. \& Robinson, J.E. 1986. New biostratigraphic evidence of the Post-glacial colonisation of Ireland and for Mesolithic forest clearance. J.Biogeog., 13, 487-509.

Robinson, E. 1986. Ostracods from Meare East. Som. Levels Pap., 12, 102-105.

Whatley, R.C. \& Haynes, J.R. 1986. Foraminifera and Ostracoda. In: Roberts, M.B.; Excavation of the Lower Palaeolithic site at Amey's Eartham Pits, Boxgrove, West Sussex: A preliminary report. Proc. Prehist. Soc., 52, 215-245. 